\title{
Strengthening the Relationship between Undergraduate Professional Preparation Programs in Parks, Recreation, and Tourism and Graduate Leisure Studies
}

\author{
Daniel Dustin \\ Laurie Browne \\ Kelly Bricker \\ Keri Schwab \\ Department of Parks, Recreation, and Tourism \\ University of Utah
}

\begin{abstract}
This article stems from a conversation among academic leaders of graduate-oriented departments of parks, recreation, and tourism across North America who participated in an administrator summit at Zion Ponderosa Resort in southern Utah September 23-26, 2010. The University of Utah's Department of Parks, Recreation, and Tourism hosted the summit, and among the many topics discussed was the need to strengthen the relationship between undergraduate professional preparation programs in parks, recreation, and tourism and graduate leisure studies. In many respects, the tension between undergraduate and graduate programs reflects the tension between research universities and the world of professional practice. We examine this tension in both contexts and recommend specific courses of action to relieve it.
\end{abstract}

KEYWORDS: Graduate education, research universities, synergistic potential, undergraduate professional preparation

Please address all correspondence to: Daniel Dustin, Department of Parks, Recreation, and Tourism, College of Health, University of Utah, Salt Lake City, Utah 84112-0920, (801)-585-7560, daniel.dustin@health. utah.edu 
In a thought-provoking essay, "The Coming Separation of Leisure Studies from Parks and Recreation Education," Rabel Burdge (1985) challenged the educational community to rethink the wisdom of offering undergraduate professional preparation programs in parks and recreation and graduate leisure studies in the same academic department. Burdge rested his case on what he perceived to be fundamental differences in what goes into the preparation of park and recreation practitioners and what goes into the scientific study of leisure. He reasoned further that differences in faculty orientation to the subject matter, curricular conflicts, methodological incompatibilities, and inapplicability of leisure research findings to improve professional practice, all work against a goodness of fit between undergraduate and graduate education.

The separation Burdge called for remains a topic of considerable debate as evidenced by a recent academic administrator summit hosted by the University of Utah's Department of Parks, Recreation, and Tourism at Zion Ponderosa Resort in southern Utah during the fall of 2010. The administrators in attendance, who represented a preponderance of graduate-oriented academic departments of parks, recreation, and tourism throughout North America, agreed that the tensions Burdge addressed in 1985 still exist. At the same time, they also agreed that separating undergraduate professional preparation programs from graduate leisure studies is not practicable, because graduate leisure studies are heavily subsidized by undergraduate tuition dollars. The administrators were left with the challenge of how best to turn what is now largely a marriage of economic convenience into something more worthwhile, mutually beneficial, and sustainable. This article responds to that challenge.

\section{Bridge Building}

In response to Burdge's essay, Geoffrey Godbey (1985), Thomas Goodale (1985), and Stephen Smith (1985) offered their own interpretations of the relationship between undergraduate professional preparation programs in parks and recreation and graduate leisure studies. While acknowledging the validity of several of Burdge's concerns, they came to very different conclusions about what ought to be done. For example, Godbey, Goodale, and Smith envisioned a future characterized by increasing synergy between undergraduate and graduate education made possible by a changing professoriate and a corresponding commitment to bridging the gap between professional preparation and the scientific study of leisure. Smith (1985), in particular, employed the metaphor of a bridge to make the point that bridges stand upright only by balancing the stresses placed on them by building solid buttresses at each end. In essence, the challenge is to make each end highly dependent on the other for the bridge to carry its weight.

In the spirit of Smith's metaphor, we also focus on structural matters undergirding what ought to be a strong bridge between undergraduate professional preparation and graduate leisure studies, because we, too, believe that the strength of each is highly dependent on the strength of the other. And it is precisely where the tensions identified by Burdge are most evident that we must reinforce the girders-the professoriate, the curriculum, and professional affiliations. It is our contention that in each case, the work to be done is on the "edges," those places that connect undergraduate to graduate education as well as those places that connect higher education to the world of professional practice. 
In many respects, these are age-old tensions. The gap between graduate leisure studies and undergraduate professional preparation is akin to the gap between basic and applied research. The gap between leisure studies scholars and park and recreation educators is akin to the gap between the Academy of Leisure Sciences and the former Society of Park and Recreation Educators. The gap between research universities and the National Recreation and Park Association is akin to the gap between research and practice. The challenge is to bridge these gaps by strengthening what should unite them, the linkages that encourage the free flow of ideas back and forth in a manner that informs both leisure studies and professional practice.

\section{Girding Up the Professoriate}

While it may be true that national reputations of departments housing graduate leisure studies are built upon the backs of faculty members engaged in leisure scholarship, and while it may also be true that such faculty members rely on a cadre of doctoral students to assist them in carrying out their research agendas, it is also true that the vast majority of those same doctoral students wind up working in undergraduate-oriented teaching colleges and universities upon completion of their doctoral studies. This means that even though those doctoral students may be well versed in the canons of scientific inquiry, they may not be so well versed in the pedagogical skills they will be called upon to employ when they begin their teaching careers-advising undergraduate majors, supervising internships, and teaching as many as four courses per academic term.

Under the circumstances, treating the graduate student experience at research universities as if it were totally independent of undergraduate education can lead to illprepared junior faculty who take positions at comprehensive, undergraduate-oriented teaching universities. While focusing on the development of research skills may serve the best interests of the faculty members with whom the doctoral students apprentice, it does not prepare the doctoral students for the undergraduate classroom many of them are about to enter. Indeed, as Rice (2005b) recently reported, "Interviews with graduate students and early career faculty disclose a serious mismatch between the doctoral preparation that most receive and the needs of the universities and colleges in which they are likely to be employed" (p. 311). Consequently, while it is important for doctoral students to master social science research methodology, it is equally important for them to master the pedagogical skills attendant to their upcoming role as teaching professors.

The opportunity for this kind of professional preparation exists at the undergraduate level. We are not suggesting that doctoral students simply be turned loose to do "practice teaching" with undergraduate majors. On the contrary, we are suggesting that administrators of departments of parks, recreation, and tourism at research universities establish formal mentoring programs that gradually build doctoral students' teaching skills in the same way they apprentice with faculty to build their research skills. This requires coursework in pedagogy as well as research methods, and it requires serving as teaching assistants and/or discussion leaders in a sequence of undergraduate core courses under the tutelage of accomplished teaching professors. Such an expanded apprenticeship not only prepares doctoral candidates to teach their own courses in the latter stages of 
their program of study, it familiarizes them with the classroom environment in which many of them will eventually work. This kind of mentoring can be extended to student advising, internship supervision, and online teaching as well.

Unfortunately, the current funding arrangement for doctoral students tends to require research hours tied to a particular faculty member's research agenda in return for a stipend and tuition waiver. This arrangement may serve the needs of the faculty member, but it does not serve the long-term best interests of the doctoral student or undergraduate teaching programs. Even if a doctoral student ends up with an appointment at a research university, teaching will be a critical part of her or his tripartite responsibility (i.e., teaching, scholarship, and service). Indeed, one of the unfortunate byproducts of focusing exclusively on a research apprenticeship is the implicit message that teaching is secondary to scholarship, or worse yet, that teaching undergraduates detracts from what really counts in higher education-scholarly productivity.

This view of research as the central professional endeavor and focus of academic life has deep roots in the history of American higher education (Rice, 2005a), but higher education's principal stakeholders-students, parents, legislators, trustees, taxpayersare increasingly making it clear that undergraduate education should be the heart of the academic enterprise, and that much more attention must be given to it. Because of their graduate focus, research universities, in particular, must thus work harder to give undergraduate education its due. This can be facilitated through a renewed commitment to equipping the future professoriate with teaching as well as research skills.

\section{Girding Up the Curriculum}

In The University: An Owner's Manual (1991), Harvard University's former dean of arts and sciences, Henry Rosovsky, makes the observation that the professors best suited to teach a field's latest findings are junior professors, not senior professors. Fresh from their own doctoral studies, junior professors are closer to a body of knowledge's cutting edge, and therefore are best suited to convey that knowledge to students. By extension, it seems reasonable to suggest that doctoral students are in a similarly advantageous position to share the fruits of what they are learning in their doctoral program of study with undergraduate student majors. Having benefited from a mentoring program that equips them with the latest research and teaching skills to convey what they know to students in an engaging and effective manner, seasoned doctoral candidates are now well-positioned to deliver that curriculum.

In this regard, one of the most important contributions graduate students can make to undergraduate education is to help create a genuine appreciation for the research process. By sharing their enthusiasm for their own master's and doctoral research projects, and by including undergraduates in those projects whenever possible, graduate students can play a leading role in demonstrating how research is intended to serve professional practice. Carried out with care, the socialization of future park, recreation, and tourism professionals into a research culture may eventually reduce the distance between research and practice that so often plagues the relationship between educators and professionals in the field. 
The prospects for such a transfer of learning are particularly exciting when mentoring professors and graduate students team up to teach a curriculum that is carefully sequenced and integrated in a way that demonstrates to undergraduate majors what ought to be the seamless nature of their education. Frequently offered in the form of an immersion or integrated curriculum, students proceed as a cohort through a series of problem-based learning experiences that not only binds them together as future park, recreation, and tourism professionals, but also bridges the chasm between their book and experiential learning. Pioneering efforts at implementing this kind of innovative problem-based curriculum are ongoing at the University of Georgia, Clemson University, and the University of Utah, among others. The driving force behind delivering the core undergraduate curriculum in this manner is a desire to reduce the distance that so often separates higher education from the world of professional practice by demonstrating the curriculum's relevance to solving problems faced by professionals in the field. This is done not at the expense of graduate leisure studies, but as a complement to graduate leisure studies. The focus is on the integration and application of theories, strategies, and tools to create a problem-based learning environment. This approach more closely resembles the applied world of professional practice.

\section{Girding Up Professional Affiliations}

In Smith's (1985) response to Burdge, he characterizes the schism between higher education and the world of professional practice as a conflict between the world of thought and the world of action. Smith goes on to suggest that "Leisure scholars are interested in deriving objective laws and in defining general, abstract patterns. The driving force for managers (and management trainers) is to learn from experience and to interpret experience on the basis of personal or agency values" (p. 156). There is a built-in difference between the demands placed on academics and the demands placed on professionals in the field. They march to the beat of different drummers. Recognizing this, the challenge is to find those linkages where research and practice can serve one another and strengthen them.

The college classroom is one of these critical linkages. Educators must do a better job of bringing park, recreation, and tourism professionals into the classroom where they can discuss issues they are facing in the field with students who are about to enter the field, as well as with faculty who are charged with ensuring their students' readiness for the field. Hiring part-time instructors from the field is one way to do this. Another is team-teaching. Yet another is getting educators, students, and practitioners alike to work together on applied research problems. These are reasonable and feasible ways to reduce the distance between the worlds of thought and action.

As Smith (1985) points out, "Faculty are expected to be producers, interpreters, or testers of new knowledge and not simply repeaters of old knowledge. Different faculty have different strengths and interests. Some are more traditional scholars; others are more interested in professional application of research discoveries. There is room for all. ..." (p. 157). Smith's observation reminds us that not all leisure scholars are interested in "deriving objective laws and in defining general, abstract patterns." Indeed, many leisure studies scholars focus on the "professional application of research discoveries." (One 
need only think of John Crompton's work to appreciate this point.) We should capitalize on the interests of applied leisure studies scholars in solidifying the relationship between higher education and professional practice. This requires developing problem-based approaches to curricular design that encourage students, faculty, and professionals to identify knowledge gaps and eliminate them in ways that lead to more effective delivery of park, recreation, and tourism services.

Smith's observation also brings to light one more crucial consideration that warrants attention if we are to strengthen the girders that bind undergraduate professional preparation programs in parks, recreation, and tourism to graduate leisure studies-the faculty reward system.

\section{Taking "Scholarship Reconsidered" Seriously}

In 1990, Ernest Boyer published Scholarship Reconsidered, an in-depth look at how scholarship is defined in higher education. He challenged the predominant view of scholarship as basic research only, and recommended broadening the definition to include the scholarship of discovery, integration, application, teaching, and service. Boyer's proposal was not intended to be a watering down of what is meant by scholarship. On the contrary, it was an attempt to honor the full range of activities professors engage in when carrying out their tripartite responsibility of teaching, scholarship, and service. Boyer's thinking reinforces what Smith (1985) said about faculty members' differing strengths and interests, and it echoes Smith's sentiment that "there is room for all" when it comes to rewarding good work. The challenge is to resist thinking of teaching, scholarship, and service as separate endeavors, and to reject the notion that one individual cannot be highly accomplished in all three areas. The ideal professor does justice to the tripartite responsibility, and the goal should be to recognize the symbiotic nature of teaching, scholarship, and service, and to encourage all faculty members to do their best to manifest it in their work (Dustin \& Goodale, 2007).

Moreover, if we are to strengthen the relationship between undergraduate programs in parks, recreation, and tourism and graduate leisure studies, we have to honor faculty contributions to undergraduate professional preparation as well as to graduate leisure studies. This requires rethinking our orientation to the academic enterprise in research universities, where it is common to view a candidate's readiness for tenure and promotion based largely on contributions to basic research published in refereed journals with high rejection rates. Such a narrow view of what "counts" does an injustice to the full array of meaningful contributions faculty members make to the scholarship of integration, application, teaching, and service as well as to the scholarship of discovery. As Smith (1985) concludes, healthy academic departments are characterized by a wide diversity of faculty interests and talents. The administrative challenge is how best to encourage the full blossoming of those interests and talents and reward them accordingly (see Wellman, Dustin, Sharik, \& Schleien, 2006; Rice, 2005a \& 2005b; Gaff, 2005). 


\section{Conclusion}

An important first step in strengthening the relationship between undergraduate professional preparation programs in parks, recreation, and tourism and graduate leisure studies is to broaden the concept of scholarship in the socialization of future professors. Gaff (2005) characterizes the challenge thusly:

When graduate students are forming their ideas about research and scholarship and developing their professional identities, it is important that they take a broad view of scholarship. They must see the intellectual value of connecting ideas across academic disciplines, applying abstract ideas to real-world problems, and gaining theoretical insights from practice. They should also learn about the mysteries of communicating their specialty to nonspecialists, which is to say, to teach the subject so that others can learn. And they should understand the range of scholarship that can lead to discoveries and can be done within the constraints of different kinds of institutions. By understanding the breadth of the intellectual terrain, graduate students can find their own niche, where they can contribute to teaching and research and derive satisfaction in their own careers (pp. 69-70).

We have identified a number of places where undergraduate professional preparation programs and graduate leisure studies intersect. These intersections provide ideal opportunities for demonstrating the scholarship of discovery, integration, application, teaching, and service. Moreover, they are ideally situated for what Rice (2005a) and others call the "scholarship of engagement," the scholarship of genuine collaboration among faculty, doctoral students, master's students, undergraduate students, and professionals in the field. The scholarship of engagement proceeds from the assumption that teaching and learning are multidirectional and that expertise is shared among a wide range of individuals with a wide range of personal and professional experiences. Ultimately, it is the scholarship of engagement that ties the undergraduate professional preparation program to graduate leisure studies and graduate leisure studies to the world of professional practice.

The importance of the scholarship of engagement to the long-term viability of leisure studies cannot be overstated. Indeed, as Smith (1985) concluded in his response to Burdge (1985), in the absence of demonstrating leisure studies' relevance to the resolution of society's pressing social and environmental problems, leisure studies is at risk as an area of academic inquiry. Fortunately, leisure studies scholars are now beginning to demonstrate this relevance through research on community service learning (Arai \& Pedlar, 2003), civic engagement (Glover \& Stewart, 2006), social capital (Glover, 2004), and matters of social and environmental justice (Mair \& Reid, 2007; Paisley \& Dustin, 2011). If, as Karla Henderson (2010) recently suggested, part of the reason our field is in crisis is because we have not demonstrated leisure's fundamental contributions to the public good, then it is incumbent on higher education to honor and reward the kind of scholarship dedicated to making those contributions explicit-the scholarship of engagement. 
Considered collectively, the opportunities we have described in this article illustrate the synergistic possibilities when undergraduate professional preparation programs are bound together with graduate leisure studies in a way that can benefit park, recreation, and tourism services. The challenge is to take advantage of this synergistic potential to reinforce the connections that should unite, rather than divide, undergraduate and graduate education and higher education and the world of professional practice.

\section{References}

Arai, S., \& Pedlar, A. (2003). Moving beyond individualism in leisure theory: A critical analysis of concepts of community and social engagement. Leisure Studies, 22, 1-18.

Boyer, C. (1990). Scholarship Reconsidered: Priorities of the Professoriate. Princeton, NJ: Carnegie Foundation for the Advancement of Teaching.

Burdge, R. (1985). The coming separation of leisure studies from parks and recreation education. Journal of Leisure Research, 17 (2): 133-141.

Dustin, D., \& Goodale, T. (Eds.). (2007). Making a difference in academic life: A handbook for park, recreation and tourism educators and graduate students. State College, PA: Venture.

Gaff, J. (2005). Preparing future faculty and multiple forms of scholarship. In O'Meara, K., \& Rice, R. (eds.) Faculty priorities reconsidered: Rewarding multiple forms of scholarship. San Francisco: Jossey-Bass, pp. 66-71.

Glover, T., \& Stewart, W. (2006). Rethinking leisure and community research: Critical reflections and future agendas. Leisure/Loisir: Journal of the Canadian Association for Leisure Studies, 30 (2): 315-327.

Glover, T. (2004). Social capital in the lived experiences of community gardeners. Leisure Sciences, 26 (2): 143-1

Godbey, G. (1985). The coming cross-pollination of leisure studies and recreation and park education: A response. Journal of Leisure Research, 17 (2): 142-148.

Goodale, T. (1985). Carts before heavy mules: Are competing hypotheses too late? Journal of Leisure Research, 17 (2): 149-154.

Henderson, K. (2010). Leisure studies in the 21st century: The sky is falling? Leisure Sciences, 32 (4), 391-400.

Mair, H., \& Reid, D. (2007). Leisure research and social change: A millennial state of the art. Leisure/Loisir, 31 (2), 501-522.

Paisley, K., \& Dustin, D. (Eds.). (2011). Speaking up and speaking out: Working for social and environmental justice through parks, recreation, and leisure. Champaign, IL: Sagamore.

Rice, R. (2005a). "Scholarship reconsidered": History and context. In O’Meara, K., \& Rice, R. (Eds.), Faculty priorities reconsidered: Rewarding multiple forms of scholarship. San Francisco: Jossey-Bass, pp. 17-31.

Rice, R. (2005b). The future of the scholarly work of faculty. In O'Meara, K., \& Rice, R. (Eds.) Faculty priorities reconsidered: Rewarding multiple forms of scholarship. San Francisco: Jossey-Bass, pp. 303-312.

Rosovsky, H. (1991). The university: An owner's manual. New York: W. W. Norton \& Company. 
Smith, S. (1985). An alternative perspective on the nature of recreation and leisure studies: A personal response to Rabel Burdge, Journal of Leisure Research, 17 (2): 155-160.

Wellman, D., Dustin, D., Sharik, T., \& Schleien, S. (2006). Rethinking the faculty reward system for department chairs. The Department Chair, 17 (1): 1-3. 